\title{
RUSSIAN-ISRAELI RELATIONS: THE ROLE OF THE RUSSIAN-SPEAKING COMMUNITY OF THE STATE OF ISRAEL
}

\author{
T.D. Moshkova \\ Saint Petersburg State University, Saint Petersburg, Russian Federation
}

\begin{abstract}
The article is devoted to the study of the large and actively developing community of Israel - the "Russian street" - and its influence on the relations between Israel and Russia. The author considers such aspects of the topic as: the differences of the "Great Aliyah" of the 1990's from the first wave of repatriation of the 1970's and the factors that formed the unique "Russian-Jewish" identity among the representatives of the "Russian street", the political and economic potential of "Russian Israel", the main areas of cooperation between the two states and the role of the "Russian" community in this cooperation. A specific feature of the work is the use of the hermeneutic approach which is expressed in the author's desire to comprehend the unique identity of a specific cultural community and to identify a number of factors that have decisively influenced the formation of a unique identity of such a community in a specific historical period. The author also resorts to general scientific procedures and operations, such as analysis and synthesis, inductive and deductive methods. The scientific novelty of the research is the author's attempt to give a forecast concerning the possibility of forming a pro-Russian economic lobby among Israeli businessmen in the future as well as a forecast concerning the return of our former compatriots to Russia with the goal of developing the domestic high-tech industry. The main conclusion of the study is the following: if politically the community does not have a decisive influence on the actions of the Israeli authorities, then economically, it unequivocally contributes to strengthening economic ties between Israel and Russia. Russia's initiatives to develop various forms of economic, cultural and media cooperation can give impetus to the growth of the influence of the Russian-speaking community.
\end{abstract}

Key words: aliyah, lobby, repatriates, the Russian street, The State of Israel, Russia-Israel cooperation

The problem of migration processes related to the State of Israel seems to be relevant, since Israel, in fact, is a country built by repatriates. Since the establishment of the State, about three million people of Jewish descent from eighty countries of the world have made repatriation ${ }^{1}$. But ethnic, linguistic and confessional uniformity was not achieved in Israel (unlike in other immigrant societies). As a result, the society has split into separate sub-ethnic groups, and that influences the foreign policy of the State.

The subject of the study is the Russian-speaking community of the State of Israel and its role in establishing relations between Israel and Russia. Being an autonomous formation within Israeli society, the "Russian street" mainly includes people with a high level of education, which makes it possible to say that "Russian Israel" puts some emphasis in relations with the motherland of returnees.

${ }^{1}$ Lishka statistika rashii shel Israel. Netugim muvharim mi mishal sotsiali al ivrit ve shimush be safot aherot (The Central Israeli Bureau of Statistics. Selected Data from the Social Survey on Mastery of the Hebrew Language and Usage of Languages (in Hebrew). URL: http://www1.cbs.gov.il/ reader/newhodaot/hodaa_template.html?hodaa=201319017 (accessed: 29.10.2017). 
There is a point of view according to which the peak of the activity of the "Russian street" occurred at the end of the 1990's, and after that the process of the disappearance of the community began [Khanin 2014: 22]. This point of view is held by E. Leshem, who writes about the completion of absorption in one or two generations [Leshem 2007: 283]. However, the current situation makes it possible to assert that the Russian-speaking community is still legitimate as a long-term phenomenon, which is precisely the community [Remennik 2008: 167], although the question of how the "Russian" Jews in Israel possess the classical structural features inherent in the communities remains open.

The fact is that it has a specific character and a number of atypical parameters: a system of informal relations with a high intensity, family support functions, a clear boundary between the community and the external environment. Natives of the former Soviet Union have formed a community that is a special society in which Russianspeaking Israelis create their own cultural and behavioral autonomy characterized by an isolated nature of the communication environment and forms of social and cultural life that differ sharply from the forms of social and cultural life of the indigenous Israelis - sabra.

With all the diversity of associations of the returnees from the countries of the former USSR, the subculture of the "Russian street" is not homogeneous and does not cover $100 \%$ of the repatriate community. However, despite the fact that some part of the community is outside the subculture, the fact of existence of the phenomenon of the "Russian street" allows its representatives to feel their importance and not to develop their potential only within the community cell but to offer it to the whole Israeli society. Therefore, the fact of broad involvement of immigrants from the countries of the former Soviet Union in the politics does not seem random. The question was only in the search for an adequate form of institutionalization of the Russian-speaking community with the goal of turning it into a full-fledged "Russian lobby".

This question is also debatable among the political elite of Russian-speaking Israelis today. Since 1993, two groups have emerged in this milieu, the first of which was convinced of the need for a purely sectoral party, believing that only such a party would be able to consolidate the community's forces, prevent their dispersion, and stop the confrontation among the new repatriates and to fully lobby the interests of the community and its emerging elites. The second group spoke only of the necessity of the existence of a "Russian wing" within the framework of Israeli parties and political movements and the use of their mechanisms to achieve the goals of "Russian Israel". Ten years later, in 2003, Russian immigrants proved that the structural and ideological differences within the community cell cost more than integration tendencies within the community [Khanin 2008: 98-116].

The "Great Aliyah" of the 1990's coincided with the process of legitimizing the "multiculturalism" in Israel, which contributed to the legitimization of the social institutions of the "Russian" community and played a role in shaping a unique identity among the representatives of the "Russian street". The Israeli political establishment positively perceived the maturation of the subculture of "Russian" repatriates in the society.

There is a phenomenon of the concentration of returnees from the former USSR within certain districts. In such areas, community-forming links are formed, which can 
be considered as a compensator of the negative consequences of the absorption of the "Great Aliyah". In turn, these communal ties helped to increase the level of the cultural self-sufficiency among the representatives of the "Russian street" and the desire to preserve and reproduce their habitual forms of social, cultural and professional interaction. This can be confirmed by a study conducted in 2006 by the Joint Israel organization. $90 \%$ of the "Russian" immigrants responded that 15 years after their repatriation they continue to live in a traditionally immigrant area. Moreover, $90 \%$ of the young respondents aged 18 to 29 claimed to have some degree of Hebrew language, but at home they continue to speak Russian [Khanin 2014: 25].

Another illustrative example of the cultural self-sufficiency of immigrants from the countries of the former USSR can be the fact that only one third of the respondents noted that among the members of their families there are those who did not marry a representative of the "Russian street" [Khanin 2014: 26]. The study of civil identity also showed that among the young immigrants aged 18-28 years the percentage of those who claimed that their four closest friends out of five were representatives of the "Russian street" was the highest. Moreover, 57\% of respondents stated that they are in constant contact with their "Russian" friends, which indicates the effective functioning of social ties within the Russian-speaking community.

However, it is wrong to assert today that the "Russian" community is a kind of a "Russian ghetto" because, according to the same poll by the Mutagim agency, young immigrants are also actively involved in Israeli reality and are in contact with indigenous Israelis and returnees from other countries. At the same time, only $34 \%$ of the middleaged respondents and $15 \%$ of the older respondents establish contacts with Israeli citizens without distinction of their origin [Khanin 2014: 127].

The key aspect of the subculture of "Russian" Jews and the factor of their rallying is the preservation of the unique status of the Russian language in Israel and its place in the media space of the country. It became a legitimate means of communication within the community [Niznik 2003: 49-60]. The Ministry of Aliya and Absorption is tolerant to the use of the Russian language in the practice of state institutions and in the media. Russian is also introduced into the curricula of Israeli schools as the third language. The Ministry of Education provided Russian-speaking immigrant pupils with the opportunity to use the texts in Russian at the TANAKH (Jewish Scripture) examinations, as well as the opportunity to pass the exams in the native language under the secondary school program. In the 2011-2012 school year the Ministry of Education decided to increase the hours of studying Russian language by $25 \%$, as well as to increase the hours allocated for passing the refresher courses for the teachers of the Russian language by $50 \%$. The listed initiatives of state bodies of Israel correspond to the needs of representatives of the Russian-speaking community who use the Russian language and Hebrew equally.

Russian language is studied by seven and a half thousand schoolchildren in one hundred and fifty Israeli schools. 95\% of students were born in the countries of the former USSR or in Israel in the families of the Russian-speaking immigrants. The length of stay in Israel of students is from zero to seventeen years. Their level of language proficiency differs, but for the majority Russian is not a native language, but a language of a "cultural heritage" [Niznik 2010: 6]. 
The Russian language of the repatriates is very different from the Russian language of the Russians [Donnitsa-Shmidt 2007: 57-64]. It should be viewed not as the evidence of the "Russian universalism", but as a proof of the existence of the phenomenon of integration of the Russian-speaking repatriates into Israeli society without subsequent acculturation. Russian-speaking repatriates see it as their goal to preserve the cultural baggage with which they moved to Israel [Khanin 2014: 32].

There are some historical roots of the influence of Russian-speaking repatriates on interstate relations. And this is not just a consequence of mass repatriation of Russian-speaking Jews in the early 1990's and of specific features inherent in the "Russian street". The key point is the fact that Israel and Russia had close ties throughout the 20th century, even though in the period from 1967 to 1991 diplomatic relations between states were broken [Morozov 2003: 178]. Israel adopted the experience of the state building both of the Russian Empire and of the Soviet Union, which manifested itself in combination in the State of Western and Eastern political traditions. The Israeli leadership in different years borrowed some elements of the Russian experience of economic construction. As an example, we can name Vysotsky's company, which comes from pre-revolutionary Russia, and now controls most of the tea market in Israel [Fedorchenko 1998: 125].

The political orientation of the repatriates created an environment for cooperation in Palestine. The repatriates started the development of "working democracy" within the business activities of the trade union "Histadrut" [Zvyagelskaya, Karasova, Fedorchenko 2005: 155]. Immigrants from Russia brought their political views to the Palestinian lands, including a trend towards socialist experiments and the desire to build a Russian socialist utopia in Palestine. Many Russian Zionists were members of the Narodnik organizations and later joined the Socialist Revolutionaries [Khanin 2004: 127]. The political views of the returnees put some new collectivist ideas into classical Zionism by T. Herzl, which implied the development of private entrepreneurship on the Palestinian land. This led to the large-scale establishment of kibbutzim. As a mass and diverse in form, cooperation in Israel was similar to the Russian version of cooperation, therefore, before the formation of the State, especially during the 1920's, it developed in the same way as the first rural communes and collective farms in the USSR [Kupovetsky 2000: 134].

There is an imbalance between the influence that the Russian-speaking community has on Israel's policy and the influence that the "Russian street" has on the Israeli economy and the development of Israeli-Russian economic ties. Today the potential of the "Russian street" in the political field is relatively low. The Russian-speaking community does not represent a key factor in influencing the internal policy of the State, it affects only the dynamics of relations between Russia and Israel. The conditions for the growth of the influence of the "Russian street" are the preservation by the migrants from Russia of their national identity; preservation of the Russian language and its introduction into the education system; the interaction of the Russian-speaking community of Israel with the Jewish diaspora in Russia through a variety of cultural projects. In particular, educational seminars on the basis of Jewish youth organizations in Russia, such as "Hillel", "Yahad" and "Enerjew", contribute to the popularization of Israeli culture. 
As for a shaping the course of the state's foreign policy towards Russia, today it is also impossible to talk about the great role of the Russian-speaking repatriates. Nevertheless, the "Russian Israel" in this regard has unrealized potential, in connection with which the Russian side needs to work more with the Russian-speaking segment in Israel.

In the economic sphere, the potential of the community is much higher, which is due, first of all, to the composition and structure of the "big wave of repatriation" of the 1990's. Comparing the repatriation of the period of the "Great Aliyah" with the first wave of immigration in the 1970's, it is possible to note a large number of specific features of the "aliyah of the 1990's". It is necessary to take into account the fact that all waves of repatriation took place in absolutely different periods of the domestic political situation in the country of origin. During the 1970's there was a large number of activists of the Zionist movement, in particular, members of the organization "Prisoners of Zion" among the returnees. Zionism in the countries of the former Soviet Union was an ideology hostile to the basic ideology, so until the late 1980's. Zionist activities in the country were banned. Repatriates of the 1970's sought to the "Promised Land" because they could not reconcile themselves to the situation of Jews in the USSR, with the infringement of their religious and political rights, as well as with manifestations of antiSemitism in one form or another [Horowitz 1998: 514].

For the immigrants of the "Great Aliyah" period, Israel could become a country that would unconditionally provide them with assistance. Repatriation occurred, first of all, not because of the Zionist views of immigrants, but because of anti-Semitism and the difficult life circumstances that resulted in returnees being forced to leave the country of origin. In contrast to the previous wave, the "Great Aliyah" in the bulk consisted of people of Jewish origin, but far from Judaism, Jewish culture, traditions, Hebrew, Zionist ideology, almost indifferent (especially the younger generation) to the problems of Jewish self-identification. For the most part, among the "Great Aliyah" repatriates, there was no sense of solidarity with the indigenous inhabitants of Israel the Sabra [Lissak, Leshem 1995: 22].

A large percentage repatriated from Moldova, the Transcaucasian republics, the Ukraine due to the deterioration of the economic and political situation in these regions; the new olim (repatriates) almost completely lacked ideological or religious reasons for repatriation. The overwhelming majority of them were secular Jews, only a small part (according to polls) "observed some traditions" [Adler 1997: 132]. The fear of political and economic instability in the CIS countries was one of the main reasons to leave. The deterioration of the economic situation, living conditions, growing unemployment in many CIS countries have become significant arguments in favor of aliyah. According to public opinion polls, among the reasons for leaving one of the central places was the desire to provide the new generation with a stable future [Adler 1997: 144]. It is noteworthy that, among the arguments in favor of repatriation in the immigrant community of the "Great Aliyah" period, there was no argument related to manifestations of anti-Semitism, which was characteristic of the 1970's aliyah.

Thus, on the one hand, the repatriates of the 1990's are less ideologized than the repatriates of the previous wave. At the same time, the educational level of the repatriates 
of the "Great Aliyah" was very high. This wave of repatriation included a large number of certified and graded specialists. $40.5 \%$ of repatriates had a total training experience of 13 years, while among indigenous Israelis this percentage is much lower $(24.2 \%)$ [Adler 1997: 137]. $60 \%$ of the new olim were specialists with higher education, among the sabers this category is $28 \%$ [Remennik 2008: 169]. Thus, after the "Great Aliyah", Israel's population not only increased by $13 \%$ as a whole, but also the number of researchers increased by $41 \%$, which led the country to the first place in the world in terms of the number of scientists per capita [Adler 1997: 143]. The professional structure of immigrants looked as follows: 73,000 engineers (twice as many as the number of saber engineers), 15,200 doctors (almost equivalent to the number of Israeli doctors), 16,100 nurses, 33,600 teachers, 11,700 scientists, 15,100 representatives of creative professions (artists, writers, journalists) [Leshem, Lissak 1999: 174].

Such a high level of education, cultural and intellectual potential of the representatives of the "Russian street" determined the employment of repatriates in the technology industry, in applied technologies, in the banking sector, in the defense industry, and in entrepreneurial activity [Feldman 2003: 351].

Problems of immigrants in Israel are dealt with by the Jewish Agency, which was created in 1929, the Ministry of Aliya and Absorption, founded in 1968 and the government commission on the absorption of immigrants. Despite the considerable experience gained by Israel in the absorption of new olim, there is some discrepancy in the approaches to solving the problems of absorption and adaptation of immigrants at the conceptual level. There are several forms of absorption: the first focuses on traditional values, the second on atheism and anticlericalism, the third focuses on the idea of a "melting pot"; the fourth assumes a pluralistic model for the development of Israeli society.

The first steps to structuring the policy in relation to the use of "diaspora languages", including Russian, in the practice of state institutions took place in 1989-1992 against the backdrop of the de facto introduction of language by the structures of the "free market" (banks, intermediary offices, retail chains, etc.).

The contribution that the repatriates of the "Great Aliyah" made to the economic development of the country is of special value because the composition and the structure of the new olim fully corresponded to the economic development plan of Israel, in which the stake was made on small and medium-sized businesses based on high-tech production. To speed up the process of including specialists trained in Russia in the production process, the State of Israel created and financed various funds supporting scientific personnel and technological "greenhouses" in which scientific developments were carried out [Vardimon 2003: 115].

The commitment of the representatives of the "Russian street" to the market principles is also of great importance. This may seem paradoxical, but the "Russian" returnees with a socialist past are very different from indigenous Israelis in terms of business activity. If sabers are used to the active state intervention in the economy and to the strong state care in all spheres of society, the "Russian Israel" is known for its orientation toward creating a market economy. 
The cooperation of Russia and Israel in the field of innovative technologies can be effective for a number of reasons. Firstly, Israel today is the leading country in terms of the number of start-ups per capita ${ }^{2}$. From 1991 to 2013 the government invested about 1,900 projects with total state investments of $\$ 730$ million. More than 1600 projects have grown to independent companies and were released from the incubator. $60 \%$ successfully attracted private capital. By 2013, 35\% of the graduates are still active. According to the total amount the private investment amounted to 4 billion dollars. Thus, 5- 6 dollars of private capital were attracted for each state dollar ${ }^{3}$. Russia is striving to develop this sphere today, therefore Israel's experience in this field will be extremely useful. For Israel, the cooperation established on an equal footing will be beneficial because of the fact that until now, in the economic relations with the West, Israel was in the background.

Secondly, the absence of a language barrier between Russian and Israeli scientists is important. This will not only allow the transfer of technology between the two states, but also avoid the diversion of technology from both countries to the United States.

Thirdly, the projects for the opening of production on the territory of Russia with the involvement of Israeli capital are also beneficial for both sides. Israel may be interested in such projects, since production on its territory is much more expensive, for Russia it is an opportunity to revive a number of industrial facilities and provide a part of the population with new jobs.

However, the practical cooperation between Russia and Israel speaks of a different trend. Statistics shows that the structure of trade between Russia and Israel has not changed in recent years. Russia continues to supply the goods of the fuel and raw materials group, diamonds and products of the agro-industrial complex to Israel. Israel supplies food products, high-tech products, motor vehicles and medicines to Russia. Bilateral trade is in stagnation today. Foreign trade turnover between Russia and Israel is only 2343.8 million dollars ${ }^{4}$. As it appears in the special information of the Russian News Agency, "According to the Federal Customs Service of the Russian Federation, Russian exports amount is 1,537.7 million US dollars, imports - 806.1 million US dollars"

2 Summary of Israeli High-Tech Capital Raising-Q4/2015. IVC Research Center. URL: http://www.ivc-online.com/Research-Center/IVC-Publications/IVC-Surveys/High-Tech-CapitalRaising (accessed: 29.10.2017).

${ }^{3}$ Ibid.

4 Foreign trade of Russia with Israel (2015). Portal of the Ministry of Economy. URL: http://economy.gov.ru/wps/wcm/connect/74f394b4-59d5-4b2d-a14b-9bf7442cdc8a/\%D0\%92\%D0\% BD\%D0\%B5\%D1\%88\%D0\%BD\%D1\%8F\%D1\%8F+\%D1\%82\%D0\%BE\%D1\%80\%D0\%B3\% D0\%BE\%D0\%B2\%D0\%BB\%D1\%8F+\%D0\%A0\%D0\%BE\%D1\%81\%D1\%81\%D0\%B8\%D0\% $\mathrm{B} 8+\% \mathrm{D} 1 \% 81+\% \mathrm{D} 0 \% 98 \% \mathrm{D} 0 \% \mathrm{~B} 7 \% \mathrm{D} 1 \% 80 \% \mathrm{D} 0 \% \mathrm{~B} 0 \% \mathrm{D} 0 \% \mathrm{~B} 8 \% \mathrm{D} 0 \% \mathrm{BB} \% \mathrm{D} 0 \% \mathrm{~B} 5 \% \mathrm{D} 0 \% \mathrm{BC}+\%$ 282015\%29.pdf?MOD=AJPERES\&CACHEID=74f394b4-59d5-4b2d-a14b-9bf7442cdc8a (accessed: 04.11.2017); Foreign trade of Russia with Israel in the $1^{\text {st }}$ quarter of 2016. Foreign trade portal of Russia. URL: http://russian-trade.com/reports-and-reviews/2016-07/vneshnyaya-torgovlya-rossiis-izrailem-v-1-kvartale-2016-goda/ (accessed: 04.11.2017).

5 Interstate relations between Russia and Israel. URL: https://ria.ru/spravka/20160316/ 1390260072.html (accessed: 02.11.2017). 
Another obstacle to the establishment of Russian-Israeli economic relations is the fact that Russia pursues an isolationist policy in which Russian investments abroad are perceived as unpatriotic. The realities of geopolitics today show that the West is trying to reduce cooperation with Russia which has an impact on partners of Western countries, including Israel. With such a conjuncture, it is difficult to set up a bilateral mechanism for financing cooperation in the field of innovation. The solution to the problem may be the establishment of a bilateral fund to support R\&D. Such funds already operate between Israel and the United States, Canada, Singapore, South Korea and Germany [Mar'yasis 2015: 125].

Talking about the measures that will contribute to increasing the influence of the "Russian street" on the formation of the Israeli foreign policy, the following areas can be singled out.

First of all, it is necessary to promote projects that involve the activity of the Russian entrepreneurs in the Israeli market. Today, however, there is a clear imbalance in the mutual flow of capital. If businessmen from Israel are very active in the market in Russia, foreign entrepreneurs do not allow Russian competitors to enter the market. This kind of rejection by Israeli entrepreneurs is attributed to the negative image of Russian business in the world [Leshem, Lissak 2000: 48]. It seems that the true reason is still the fact that Sabra businessmen and foreign entrepreneurs who have already divided the Israeli market among themselves are afraid of competition from their Russian counterparts. Overcoming this obstacle is possible only with the assistance of the Russian-speaking community. In particular, the Russian-Israeli Business Council was established in 2010, whose main task is to develop business as the most effective format for the development of bilateral trade and economic relations between Russia and Israel $^{6}$.

The Russian side needs to develop cooperation with the "Russian street" of Israel through the expansion of the Russian cultural space in the State. One of the important directions is cooperation with the Russian media of Israel, which turned from the sociocultural phenomenon into a political weapon during their existence. It is necessary to increase the number of such materials published in Russian media in Israel, which would clearly explain Russia's position on various issues. This will serve to shape the Israelis' positive image of Russia, and the level of anti-Russian rhetoric in the State will decline. In economic terms, it is necessary to form a pro-Russian lobby in the State, which could be composed of businessmen who are doing business simultaneously in Russia and Israel and advocating for even greater strengthening of trade, industrial and economic ties between the two countries.

Another aspect of the interaction with the Russian-speaking community of Israel is connected with the prospect of returning to their former homeland. If in the 1990's the problem of repatriation was not on the agenda in Russia, today it is obvious that not only the flow of emigration needs to be contained, but also the return of those who live in other countries. The Russian-speaking community of Israel is the object of Russian

${ }^{6}$ Russian-Israeli Business Council. URL: http://rus-israel.ru/about/pologenie-o-sovete/ (accessed: 29.10.2017). 
authorities' guardianship, since Russian-speaking immigrants, as already noted, have a high educational level, so their return to Russia will positively affect the development of the domestic high-tech industry, science, financial industry, military-industrial complex, foreign trade and international entrepreneurship.

At the same time, the representatives of the "Russian street", who fall under the definition of "Toshav Khozer" ("the returning Israeli" 7 ) may be useful for Russia, even if they decide to stay in Israel, since "Russian Israel" today took its niche in the political life of the State. Despite the loss in 2003 and then the end of the existence of one of the political wings of the "Russian street" — Nathan Sharansky's "Israel Ba-Aliyah" party, another "Russian" party — "Israel Our Home" - continues to participate in the elections and receive mandates in The Knesset. It is legitimate to even argue that with the disappearance of the main competitor - the Sharansky's party - from the political arena of Israel, Avigdor Lieberman's party strengthened its positions even more, as it received a part of the "home electorate" of "Israel Ba-Aliyah". In the elections to the Knesset in 2009, "Israel Our Home" received 15 mandates, in the elections of 2015 - 6 mandates [Morozov 2015: 26]. The closeness of the Lieberman's party to the ruling "Likud" party is also important. The appointment of Lieberman as a Minister of Defense of Israel in 2016 can be regarded as a kind of victory for the "Russian lobby", since this post is de facto the second most important post for the State of Israel.

Talking about the prospects for the return of our former compatriots, we can predict the mobility of repatriates according to the "pendulum" migration scheme. A large number of Israeli families of the "Russian" Jews will live between the two countries in the short term. This will create a new layer of the Israeli population, which can become a strong link between Israel and Russia.

There is a point of view that the State of Israel is a prototype of what the USSR would be if the NEP was preserved and the multi-party system existed in the country [Morozov 2015: 25]. Given the above facts, this opinion can generally be accepted.

It should be specially noted that the idea of a "melting pot" which was aimed at creating a homogenous Israeli society, failed with respect to the Russian-speaking immigrants, was combined with the complete and successful absorption of the "Russian" olim, if we consider absorption as an employment and improving the living conditions of returnees. This is one of the paradoxes of Israeli society. The experience of resettlement of new citizens, accumulated in Israel, may well be rethought and used in Russia.

If in the political field the potential of the "Russian street" remains weak, in the economic sphere it is much higher. Since the beginning of the "Great Aliyah" period, economic ties between Israel and Russia have been strengthening. The presence in the Israeli labor market of highly qualified specialists from Russia has become an impetus for the development of science-intensive industries. The "Great Aliyah" of the 1990's

\footnotetext{
${ }^{7}$ Who is considered «toshav khozer». Determination of the Ministry of Aliyah and Absorption of the status of «returned Israeli». URL: http://www.moia.gov.il/Russian/ReturningResidents/ Pages/Whois2.aspx (accessed: 29.10.2017).
} 
included people with higher education and a high level of culture, which favorably distinguished them from immigrants from other countries. Moreover, two-thirds of the settlers in the country of origin were engaged in science, and over $10 \%$ of migrants had engineering education, and their number was twice the number of indigenous engineers.

Thus, the influence of the "Third Israel" on the economy and its lack of influence on politics today are obvious. To change the situation it is necessary, on the one hand, to promote the growth of the political influence of the Russian-speaking community through the building of economic cooperation through public and private partnerships, as well as through the promotion of socio-cultural and scientific projects. On the other hand, it is advisable to develop work with the Russian media of Israel, which are a powerful political weapon and the main mechanism for lobbying the interests of the "Russian street".

A number of programs of socio-political development can help to strengthen the "Russian street". Firstly, we are talking about the projects launched at the initiative of the establishment of Israel (in particular, the Jewish Agency, state institutions, trade unions and all-Israeli parties) and aimed at completing the absorption of the newly arrived immigrants to the country. Then the community puts forward its own cultural and political initiatives. And, thirdly, with the support of the Jewish Diasporas around the world, as well as the international intergovernmental and non-governmental organizations, new institutions can be established.

\section{REFERENCES}

Adler Sh. Israel's Absorption Policies since 1970's. In: Russian Jews on the Three Continents. Migration and Resettlement. Ed. by N. Lewin-Epstein, Y. Ro'i, P. Ritterband. London: Routledge, 1997, p. 135-144.

Donnitsa-Shmidt, S. (2007). Language preservation or development? The Russian language of returnees from the CIS in Israel. Ed Kha-ul'pan kha-khadash, 85, 57-64. (In Russ.).

Fedorchenko, A.V. (1998). The economy of the resettlement society (the Israeli model). Moscow: Institute for Study of Israel and the Middle East. (In Russ.).

Feldman, E. (2003). "Russian" Israel: between the two poles. Moscow: Market DS. (In Russ.).

Horowitz, T. (1998). Value-Oriented Parameters in Migration Policies in the 1990's: The Israeli Experience. International Migration, 4, 514-526.

Khanin, V. (2004). "Russians" and power in modern Israel. Moscow: Institute for the Study of Israel and the Middle East. (In Russ.).

Khanin, V. (2008). "Russian" lobby in the Israeli policy 1996-2006. Bulletin of the Hebrew University, 12 (30), 98-116. (In Russ.).

Khanin, V. (2014). "Third Israel": Russian-speaking community and political processes in the Jewish state at the beginning of the XXI century. Moscow: Institute of the Middle East. (In Russ.).

Kupovetskiy, M. (2000). Yehudei mi hamoatsot karov brit: ohlusiya ve haluka geographi [Jews of the former USSR: population and geographical distribution]. Yehudei mi hamoatsot be parashat drakhim [Jews of the USSR at the crossroads], 4, 128-135. (In Hebrew).

Leshem, E. (2007). The Russian Aliya in Israel: Community and Identity in the Second Decade. Lanham: Rowman and Littlefield Publ. Inc.

Leshem, E. \& Lissak, M. (1999). Development and Consolidation of the Russian Community in Israel. Jerusalem: Magnes Press.

Leshem, E. \& Lissak, M. (2000). Gibush shel ha kehila rusit be Israel [Formation of the "Russian" community in Israel]. Yehudei mi hamoatsot be parashat drakhim [Jews of the USSR at the crossroads], 4. (In Hebrew). 
Lissak, M. \& Leshem, E. (1995). The Russian Intelligensia in Israel: Between Ghettoization and Integration. Israel Affairs, 2, 22-23.

Mar'yasis, D.A. (2015). Experience in building the economy of innovation. An example of Israel. Moscow: IOS of RAS. (In Russ.).

Morozov, V.M. (2003). Returnees from the USSR / Russia-CIS and their influence on the political, social and economic life of the State of Israel. Moscow: Institute for the Study of Israel and the Middle East. (In Russ.).

Morozov, V.M. (2015). “Russian” Israel: the impact of repatriates on Russian-Israeli relations. Moscow: MGIMO-University. (In Russ.).

Niznik, M. (2003). Features of cultural integration of immigrants from the USSR / CIS in Israel. Diaspora, 1, 49-60. (In Russ.).

Niznik, M. (2010). Russian Language in Israel - Is it Half Alive or Half Dead? Paper, presented to the "National Challenge - the Third Ashdod Conference on Aliya and Absorption". Ashdod.

Remennik, L. (2008). "Russians" Israelis through the eyes of a sociologist: culture and way of life. Moscow: IOS RAS Natalis. (In Russ.).

Vardimon, D. (2003). Yahasei gomlin shel rashii ve lokali mosadot be Israel be zira klitat aliyah [Relations between central and local authorities in Israel in the sphere of absorption of new immigrants]. Ramat-Gan: Universita Bar-Ilan (Ramat Gan: Bar-Ilan University). (In Hebrew).

Zvyagelskaya, I.D., Karasova, T.A. \& Fedorchenko, A.V. (2005). The State of Israel. Moscow: IOS RAS. (In Russ.).

Received: 6.03.2018

For citations: Moshkova, T.D. (2018). Russian-Israeli relations: the role of the Russian-speaking community of the State of Israel. Vestnik RUDN. International Relations, 18 (2), 387-399. DOI: 10.22363/2313-0660-2018-18-2-387-399.

About the author: Moshkova Tatiana Dmitrievna - postgraduate student of Faculty of International Relations of the Saint Petersburg State University (e-mail: tata.midge@gmail.com).

\title{
РОССИЙСКО-ИЗРАИЛЬСКИЕ ОТНОШЕНИЯ: РОЛЬ РУССКОЯЗЫЧНОГО СООБЩЕСТВА ГОСУДАРСТВА ИЗРАИЛЬ
}

\author{
Т.Д. Мошкова \\ Санкт-Петербургский государственный университет, \\ Санкт-Петербург, Российская Федерация
}

Статья посвящена изучению многочисленного и активно развивающегося сообщества Израиля — «русской улицы» — и его влияния на российско-израильские отношения. Автор касается таких аспектов темы, как: отличия «большой алии» 1990-х гг. от первой волны репатриации 1970-х гг. и факторы, сформировавшие уникальную «русско-еврейскую» идентичность у представителей «русской улицы», политический и экономический потенциал «русского Израиля», ключевые сферы сотрудничества между двумя государствами и роль «русского» сообщества в этом сотрудничестве. Специфика работы состоит в использовании герменевтического подхода, который был 
выражен в стремлении автора осмыслить уникальную идентичность отдельного культурного сообщества и выявить факторы, которые главным образом повлияли на формирование данного сообщества в отдельный исторический период. Автор также прибегает к общенаучным методам исследования, таким как анализ и синтез, индукция и дедукция. Научная новизна исследования состоит в попытке автора спрогнозировать возможность формирования пророссийского экономического лобби среди израильских бизнесменов в будущем, а также сделать прогноз относительно возможности возвращения бывших соотечественников в Россию с целью развития в стране индустрии высоких технологий.

Автор пришел к следующим выводам: если русскоязычное сообщество не оказывает столь серьезного влияния на политические решения израильского руководства, то в экономической сфере оно способно укрепить контакты между Израилем и Россией. Инициативы России по развитию различных форм экономического, культурного сотрудничества и взаимодействия по линии СМИ могут дать импульс для роста влияния русскоговорящего сообщества.

Ключевые слова: алия, лобби, репатрианты, «русская улица», Государство Израиль, российско-израильское сотрудничество

\section{БИБЛИОГРАФИЧЕСКИЙ СПИСОК}

Вардимон Д. Взаимоотношения центральных и местных органов власти в Израиле в сфере абсорбции новых репатриантов. Рамат-Ган: Университет Бар-Илан, 2003. [На иврите].

Донница-Шмидт C. Сохранение языка или его развитие? Русский язык репатриантов из СНГ в Израиле // Эд Ха-ульпан ха-хадаш. 2007. № 85. С. 57-64.

Звягельская И.Д., Карасова Т.А., Федорченко А.В. Государство Израиль. М.: ИВ РАН, 2005.

Куповецкий М. Евреи бывшего СССР: население и географическое распределение // Евреи СССР на перепутье. 2000. № 4. С. 128 - 135. (На иврите).

Лешем Э., Лиссак М. Формирование «русской» общины в Израиле // Евреи СССР на перепутье. 2000. № 4. (На иврите).

Марьясис Д.А. Опыт построения экономики инноваций. Пример Израиля. Москва: ИВ РАН, 2015.

Морозов B.M. Репатрианты из СССР/России-СНГ и их влияние на политическую, социальноэкономическую жизнь Государства Израиль. М.: Институт изучения Израиля и Ближнего Востока, 2003.

Морозов В.М. «Русский» Израиль: влияние репатриантов на российско-израильские отношения. М.: МГИМО-Университет, 2015.

Низник М. Особенности культурной интеграции выходцев из СССР/СНГ в Израиле // Диаспоры. 2003. № 1. С. $49-60$.

Ременник Л. «Русские» израильтяне глазами социолога: культура и образ жизни. М.: ИВ РАН «Наталис», 2008.

Федорченко А.В. Экономика переселенческого общества (израильская модель). М.: Институт изучения Израиля и Ближнего Востока, 1998.

Фельдман Э. «Русский» Израиль: между двух полюсов. М.: Маркет ДС, 2003.

Ханин В. «Русские» и власть в современном Израиле. М.: Институт изучения Израиля и Ближнего Востока, 2004.

Ханин В. «Русское» лобби в израильской политике 1996-2006 гг. // Вестник Еврейского университета. 2008. № 12 (30). С. 98-116.

Ханин В. «Третий Израиль»: русскоязычная община и политические процессы в еврейском государстве в начале XXI века. М.: Институт Ближнего Востока, 2014.

Adler Sh. Israel's Absorption Policies since 1970's. // Russian Jews on the Three Continents. Migration and Resettlement / Ed. by N. Lewin-Epstein, Y. Ro'i, P. Ritterband. London: Routledge, 1997. P. $135-144$. 
Horowitz T. Value-Oriented Parameters in Migration Policies in the 1990's: The Israeli Experience // International Migration. 1998. № 4. P. 514-526.

Leshem E. The Russian Aliya in Israel: Community and Identity in the Second Decade. Lanham: Rowman and Littlefield Publ. Inc., 2007.

Leshem E., Lissak M. Development and Consolidation of the Russian Community in Israel. Jerusalem: Magnes Press, 1999.

Lissak M., Leshem E. The Russian Intelligensia in Israel: Between Ghettoization and Integration // Israel Affairs. 1995. № 2. P. 22-23.

Niznik, M. Russian Language in Israel - Is it Half Alive or Half Dead? Paper, presented to the "National Challenge - the Third Ashdod Conference on Aliya and Absorption". Ashdod, 2010.

Дата поступления статьи: 6.03.2018

Для цитирования: Moshkova T.D. Russian-Israeli relations: the role of the Russian-speaking community of the State of Israel // Вестник Российского университета дружбы народов. Серия: Международные отношения. 2018. Т. 18. № 2. C. 387-399. DOI: 10.22363/2313-0660-201818-2-387-399.

Сведения об авторе: Мошкова Татьяна Дмитриевна - аспирант факультета международных отношений Санкт-Петербургского государственного университета (e-mail: tata.midge@gmail.com).

(C) Moshkova T.D., 2018 